\title{
PERBANDINGAN METODE DEFUZZIFIKASI SISTEM KENDALI LOGIKA FUZZY MODEL MAMDANI PADA MOTOR DC
}

\author{
Sutikno, Indra Waspada \\ Program Studi Teknik Informatika \\ Universitas Diponegoro \\ tik@undip.ac.id, indrawaspada@undip.ac.id
}

\begin{abstract}
ABSTRAK
Dalam merancang sistem kontrol dengan menggunakan logika fuzzy terdapat tiga proses yaitu fuzzifikasi, evaluasi rule dan defuzzifikasi. Masing-masing proses tersebut akan mempengaruhi respon sistem yang dikendalikan. Defuzzifikasi merupakan langkah terakhir dalam suatu sistem logika fuzzy dengan tujuannya mengkonversi setiap hasil dari inference engine yang diekspresikan dalam bentuk fuzzy set kesuatu bilangan real. Hasil konversi tersebut merupakan aksi yang diambil oleh sistem kendali logika fuzzy. Karena itu, pemilihan metode defuzzifikasi yang sesuai juga turut mempengaruhi sistem kendali logika fuzzy dalam menghasilkan respon yang optimum.

Penelitian ini dilakukan dengan membandingan pada sistem logika fuzzy model Mamdani dengan menggunakan beberapa metode defuzzifikasi, yaitu metode COA (center of area), bisektor, MOM (mean of maximum), LOM (largest of maximum) dan SOM (smallest of maximum). Lima metode defuzzifikasi ini dibandingkan dengan mengimplementasikan pada sistem plant yang sama. Plant yang dipilih yaitu pada pengaturan kecepatan motor DC.

Pengujian yang telah dilakukan beberapa pemberian referensi, nilai rata-rata waktu tunda (td) terkecil dari lima kali percobaan adalah dengan menggunakan metode defuzzifikasi bisektor yaitu sebesar 0,1830 detik. Nilai rata-rata waktu naik (tr) terkecil dengan menggunakan metode defuzzifikasi MOM yaitu sebesar 0,5784 detik dan nilai rata-rata waktu penetapan (ts) terkecil dengan menggunakan metode defuzzifikasi LOM yaitu sebesar 0,7789 detik.
\end{abstract}

Kata kunci : Logika Fuzzy, Defuzzifikasi, Motor DC.

\section{Pendahuluan}

Logika fuzzy telah banyak diterapkan dalam bidang kontrol otomatis dan industri, diantaranya digunakan sebagai pengontrol pemrosesan citra, kendali motor, kendali robot, kendali pesawat terbang dan lain-lain. Telah banyak aplikasi sistem kontrol dengan menggunakan sistem fuzzy, karena proses kendali ini relatif mudah dan fleksibel dirancang dengan tidak melibatkan model matematis yang rumit dari sistem yang akan dikendalikan [5].

Dalam merancang sistem kontrol logika fuzzy terdapat tiga proses yaitu fuzzifikasi (fuzzification), evaluasi rule (rule evaluation) dan defuzzifikasi (defuzzification). Dari masingmasing proses tersebut akan mempengaruhi respon sistem yang dikendalikan [5].

Penelitian ini dilakukan perbandingan sistem logika fuzzy model Mamdani dengan menggunakan beberapa metode defuzzifikasi, yaitu metode COA (center of area), bisektor, MOM (mean of maximum), LOM (largest of maximum), dan SOM (smallest of maximum).
Lima metode defuzzifikasi ini dibandingkan dengan mengimplementasikan pada pengaturan kecepatan motor DC.

\section{Dasar Teori}

\subsection{Fungsi Keanggotaan}

Dalam bentuk fungsional, derajat keanggotaan dinyatakan sebagai fungsi matematis tertentu. Derajat keanggotaan dari masing-masing elemen dalam semesta pembicaraan memerlukan perhitungan. Fungsi matematis yang biasanya digunakan yaitu fungsi trapesium. Fungsi keanggotaan trapesium mempunyai bentuk seperti pada Gambar 1 dan dispesifikasikan oleh empat parameter $\{\mathrm{a}, \mathrm{b}, \mathrm{c}, \mathrm{d}\}$ seperti pada persamaan 1 [2].

$\operatorname{Trapesium}(x ; a, b, c, d)= \begin{cases}0, & x \leq a \\ \frac{x-a}{b-a}, & a \leq x \leq b \\ 1, & b \leq x \leq c \\ \frac{d-x}{d-c}, & c \leq x \leq d \\ 0, & d \leq x\end{cases}$ 


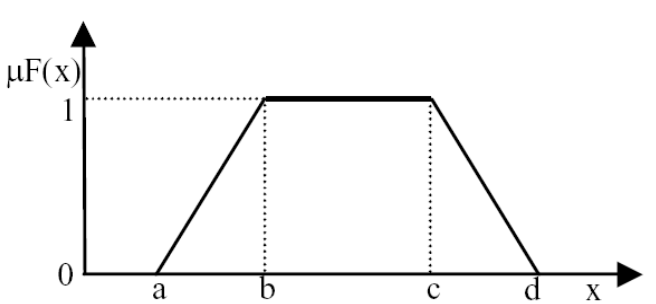

Gambar 1 Fungsi keanggotaan trapesium

Parameter $\quad\{\mathrm{a}, \mathrm{b}, \mathrm{c}, \mathrm{d}\} \quad($ dengan $\quad \mathrm{a}<\mathrm{b}<\mathrm{c}<\mathrm{d})$ menentukan koordinat $\mathrm{x}$ pada empat sudut dari fungsi keanggotaan trapesium.

\subsection{Sistem Logika Fuzzy}

Konfigurasi dasar dari sistem logika fuzzy yang digunakan seperti terlihat pada Gambar 2 [2].

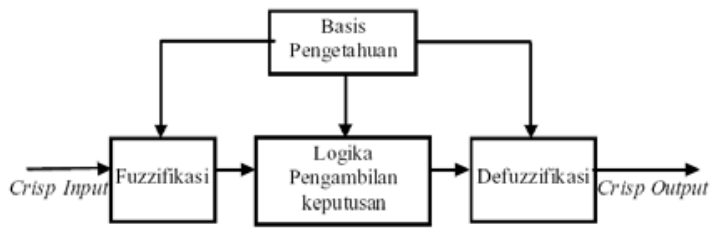

Gambar 2 Konfigurasi dasar sistem logika fuzzy

Konfigurasi sistem logika fuzzy terdapat 4 komponen utama, yaitu unit fuzzifikasi, basis pengetahuan yang terdiri dari basis data dan basis aturan, logika pengambilan keputusan, dan unit defuzzifikasi.

Proses fuzzifikasi dipergunakan untuk mengubah data masukkan tegas bentuk derajat keanggotaan. Basis pengetahuan dipergunakan untuk menghubungkan himpunan masukan dengan himpunan keluaran. Logika pengambilan keputusan dipergunakan untuk mengkombinasi aturan-aturan yang terdapat pada basis aturan suatu pemetaan dari suatu himpunan fuzzy input ke suatu himpunan fuzzy output. Defuzzifikasi adalah langkah terakhir dalam suatu sistem logika fuzzy dengan tujuannya adalah mengkonversi setiap hasil dari inference engine yang diekspresikan dalam bentuk himpunan fuzzy ke suatu bilangan real.

\subsection{Logika Pengambilan Keputusan}

Logika pengambilan keputusan (fuzzy inference) mengaplikasikan aturan-aturan fuzzy pada masukan fuzzy kemudian mengevaluasi setiap aturan. Prinsip logika fuzzy digunakan untuk mengkombinasi aturan-aturan JIKAMAKA (IFTHEN) yang terdapat dalam basis aturan suatu pemetaan dari suatu himpunan fuzzy input himpunan fuzzy output. Logika pengambilan keputusan merupakan langkah kedua dalam pemrosesan logika fuzzy. Terdapat beberapa metode pengambilan keputusan dalam logika fuzzy diantaranya yaitu metode Mamdani $[2,3]$.

Fungsi implikasi yang digunakan pada pengambilan keputusan dengan metode Mamdani dengan menggunakan MIN dan dalam melakukan komposisi dengan menggunakan MAX. Metode komposisi ini sering disebut MAX-MIN. Contoh dalam penggunaan pengambilan keputusan dengan metode Mamdani ditunjukkan pada Gambar 3 dengan memisalkan fungsi keanggotaan masukan dan keluaran menggunakan fungsi segitiga dan mempunyai 2 aturan fuzzy, yaitu:

- IF Kesalahan adalah Nol dan Beda kesalahan adalah Positif maka Keluaran adalah Positif.

- IF Kesalahan adalah Nol dan Beda kesalahan adalah Nol maka Keluaran adalah Nol.



Gambar 3 Proses pengambilan keputusan metode Mamdani.

Langkah pertama pengambilan keputusan metode Mamdani adalah melakukan proses fuzzifikasi untuk memetakan data tegas masukan kesalahan dan beda kesalahan data fuzzy sesuai 
dengan tipe dan bentuk fungsi keanggotaan. Langkah kedua adalah melakukan proses terhadap kedua data fuzzy tersebut dengan operator AND yang akan mengambil nilai paling minimal dari dua data tersebut. Langkah ketiga dengan implikasi MIN akan memotong fungsi keanggotaan keluaran setelah melalui operator AND sehingga didapatkan daerah fuzzy. Ketiga proses tersebut juga diterapkan pada aturanaturan fuzzy berikutnya. Setelah semua aturan fuzzy telah dieksekusi, dilakukan proses komposisi dengan metode MAX yaitu solusi himpunan fuzzy diperoleh dengan cara mengambil nilai maksimum aturan, kemudian menggunakannya untuk memodifikasi daerah fuzzy, dan mengaplikasikan ke output dengan menggunakan operator OR (union). Jika proposisi telah dievaluasi, maka output akan berisi suatu himpunan fuzzy yang merefleksikan kontribusi dari tiap-tiap proposisi. Setelah proses implikasi dan komposisi telah dilakukan maka proses selanjutnya adalah proses defuzzifikasi.

\subsection{Unit Defuzzifikasi}

Input dari proses defuzzifikasi adalah suatu himpunan fuzzy yang diperoleh dari komposisi aturan-aturan fuzzy, sedangkan output yang dihasilkan merupakan suatu bilangan pada domain himpunan fuzzy tersebut, sehingga jika diberikan suatu himpunan fuzzy dalam range tertentu, maka harus dapat diambil suatu nilai crisp tertentu sebagai keluarannya [3].

Ada beberapa metode defuzzifikasi pada komposisi aturan Mamdani, diantaranya yaitu metode COA, bisektor, MOM, LOM, dan SOM seperti pada Gambar 4.

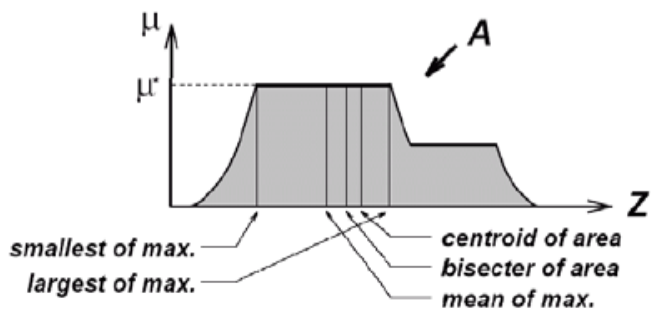

Gambar 4 Metode defuzzifikasi pada aturan Mamdani.

a. Metode COA

Pada metode ini, solusi crisp diperoleh dengan cara mengambil titik pusat daerah fuzzy, secara umum dirumuskan pada persamaan 2 untuk variabel kontinyu dan persamaan 3 untuk variabel diskrit.

$$
\begin{gathered}
z=\frac{\int_{z} z \mu(z) d z}{\int_{z} \mu(z) d z} \\
z=\frac{\sum_{j=1}^{n} z_{j} \mu\left(z_{j}\right)}{\sum_{j=1}^{n} \mu\left(z_{j}\right)}
\end{gathered}
$$

b. Metode Bisektor

Pada metode ini, solusi crisp diperoleh dengan cara mengambil nilai pada domain fuzzy yang memiliki nilai keanggotaan separo dari jumlah total nilai keanggotaan pada daerah fuzzy.

Secara umum dituliskan pada persamaan 4.

$$
\begin{aligned}
& \int_{\alpha}^{z B O A} \mu(z) d z=\int_{z B O A}^{\beta} \mu(z) d z \\
& \text { Dimana: } \\
& \alpha=\min \{\mathrm{z} \mid \mathrm{z} \in \mathrm{Z}\} \\
& \beta=\max \{\mathrm{z} \mid \mathrm{z} \in \mathrm{Z}\}
\end{aligned}
$$

\section{c. MOM}

Pada metode ini, solusi crisp diperoleh dengan cara mengambil nilai rata-rata domain yang memiliki nilai keanggotaan maksimum.

\section{d. LOM}

Pada metode ini, solusi crisp diperoleh dengan cara mengambil nilai terbesar dari domain yang memiliki nilai kenggotaan maksimum.

\section{e. SOM}

Pada metode ini, solusi crisp diperoleh dengan cara mengambil nilai terkecil dari domain yang memiliki nilai kenggotaan maksimum.

\subsection{Kendali Logika Fuzzy}

Dalam pendekatan kendali berbasis logika fuzzy, masukan, keluaran, dan tanggapan kendali dispesifikasikan sesuai dengan keahlian seorang pakar serta pemodelan matematika terhadap suatu sistem kendali tidak dibutuhkan. Prinsip dalam mendesain kendali logika fuzzy adalah mengatur parameter fungsi keanggotaan dan kaidah fuzzy [5]. 


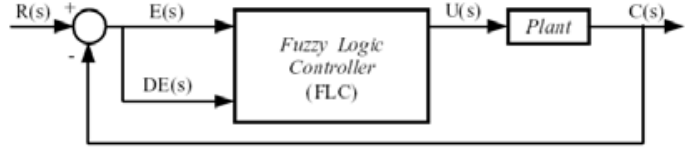

Gambar 5 Kendali logika fuzzy pada sistem kalang tertutup.

Sebuah pengendali logika fuzzy umumnya dapat dimasukkan dalam sistem kendali kalang tertutup. Gambar 5 memperlihatkan sistem kendali kalang tertutup dengan pengendali logika fuzzy dengan $\mathrm{E}$ (error) dan $\mathrm{dE}$ (delta error/ perubahan error) merupakan masukan pengendali logika fuzzy dan $U$ adalah besaran yang diberikan pada plant. Masukan error didapatkan dari nilai referensi dikurangi dengan nilai keluaran dari plant yang dinotasikan oleh persamaan 5 .

$$
\mathrm{e}(\mathrm{k})=\mathrm{r}(\mathrm{k})-\mathrm{c}(\mathrm{k})
$$

dengan:

$\mathrm{e}(\mathrm{k})$ adalah besar nilai kesalahan diskrit.

$\mathrm{r}(\mathrm{k})$ adalah besar nilai referensi diskrit.

$\mathrm{c}(\mathrm{k})$ adalah besar nilai keluaran plant diskrit

Nilai masukan beda kesalahan (perubahan error pada sistem kontinyu) didapatkan dari nilai kesalahan sekarang dikurangi dengan nilai kesalahan sebelumnya yang dinotasikan oleh persamaan 6 .

$$
\mathrm{dE}(\mathrm{k})=\mathrm{e}(\mathrm{k})-\mathrm{e}(\mathrm{k}-1)
$$

dengan:

$\mathrm{dE}(\mathrm{k})$ adalah besar nilai beda kesalahan diskrit.

$\mathrm{e}(\mathrm{k})$ adalah besar nilai kesalahan diskrit.

e(k-1) adalah besar nilai kesalahan diskrit sebelumnya.

\subsection{Definisi Spesifikasi Respon Transien}

Umumnya karakteristik performansi sistem kendali yang diinginkan dinyatakan dalam bentuk besaran waktu. Seringkali, karakteristik performansi sistem kendali dinyatakan dalam bentuk respon transien terhadap masukan tangga satuan karena mudah dibangkitkan dan cukup radikal.

Respon transien sistem kendali praktis sering menunjukkan osilasi terendam sebelum mencapai keadaan tunak. Dalam menentukan karakteristik respon transien sistem kendali terhadap masukkan tangga satuan ditunjukkan seperti pada Gambar 6 dan biasanya dicari parameter berikut [6]:

a. Waktu tunda (td), adalah waktu yang diperlukan respon untuk mencapai setengah harga naik yang pertama kali.

b. Waktu naik (tr), adalah waktu yang diperlukan respon untuk naik dari 10 sampai $90 \%$, 5 sampai $95 \%$, atau 0 sampai $100 \%$ dari harga akhirnya. Untuk sistem orde kedua redaman kurang, biasanya digunakan waktu 0 - 100\%. Untuk sistem redaman lebih, biasanya digunakan waktu naik $10-90 \%$.

c. Waktu puncak (tp), adalah waktu yang diperlukan respon untuk mencapai puncak lewatan yang pertama kali.

d. (Persen) lewatan maksimum (Mp), adalah harga puncak maksimum dari kurva respon yang diukur dari satu. Jika harga keadaan tunak respon tidak sama dengan satu, maka biasa digunakan persen lewatan maksimum. Parameter ini didefinisikan seperti persamaan 7.

Persen $\mathrm{M}_{\mathrm{p}}=\frac{c\left(t_{p}\right)-c(\infty)}{c(\infty)} \times 100 \%$

Besar (persen) lewatan maksimum secara langsung menunjukkan kestabilan relatif sistem.

e. Waktu penetapan (ts), adalah waktu yang diperlukan kurva respon untuk mencapai dan menetap dalam daerah sekitar harga akhir yang ukurannya ditentukan dengan presentase mutlak dari harga akhir (biasanya $5 \%$ atau $2 \%$ ).

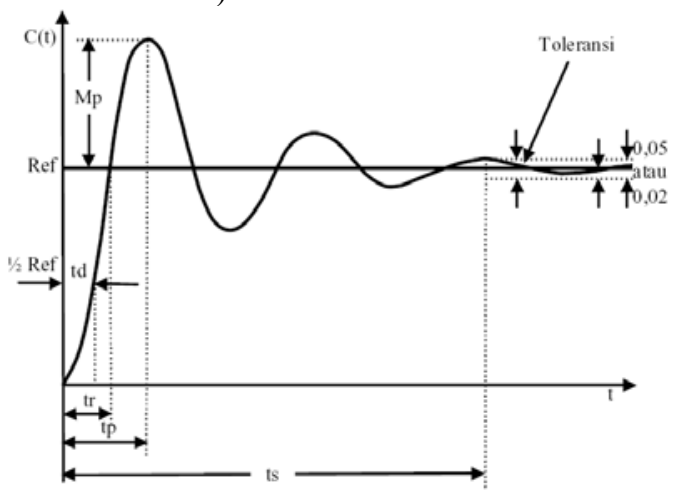

Gambar 6 Tanggapan sistem terhadap masukan tangga satuan $t d, t p$, tr, dan ts. 


\section{Pembahasan}

Perancangan pada penelitian ini terdiri dari perancangan perangkat keras dan perancangan perangkat lunak. Perangkat keras digunakan untuk mengubah data digital dari komputer menjadi data analog sebagai driver motor DC dan membaca putaran motor DC. Perangkat lunak digunakan untuk mengendalikan sistem kendali logika fuzzy yang akan mengatur kecepatan motor DC.

\subsection{Perancangan Perangkat Keras (Hardware)}

Secara umum blok diagram sistem pengendalian kecepatan motor DC yang akan dibuat pada penelitian ini dapat dilihat pada Gambar 7.

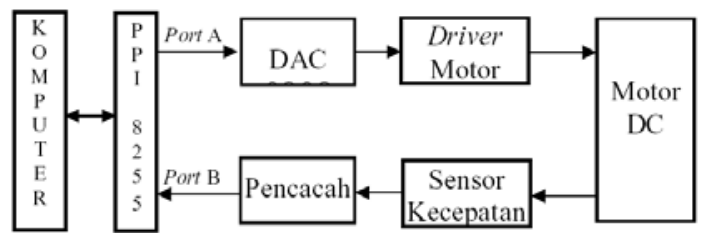

Gambar 7 Diagram blok sistem pengendalian motor DC.

Rangkaian DAC 0808 berfungsi untuk mengubah data digital dari komputer menjadi data analog berupa tegangan. Level tegangan ini digunakan sebagai masukan driver Motor DC. Pencacah dipergunakan untuk menghitung pulsa-pulsa yang dihasilkan oleh sensor kecepatan ketika motor berputar dalam waktu tertentu. Hasil dari pencacah ini dibaca oleh komputer sebagai umpan balik dari kecepatan motor DC. Komputer dipergunakan untuk merancang sistem kendali logika fuzzy, menampilkan grafik respon sistem, dan menyimpan data ke file untuk keperluan analisis.

\subsection{Perancangan Perangkat Lunak (Software)}

Program aplikasi sistem kendali logika fuzzy yang dipergunakan untuk pengaturan kecepatan motor DC ini dibuat dengan bahasa pemrograman Visual Basic 6.0 yang dapat digunakan untuk mengetahui respon sistem kecepatan motor secara on-line. Program aplikasi ini terdiri dari 3 buah form dan 2 buah modul, yaitu form utama, form EditLabel, form Data, modul1, dan modul2. Form utama digunakan untuk perhitungan kontroller logika fuzzy dan menampilkan respon sistem berbetuk grafik. Form EditLabel digunakan untuk mendesain batasan batasan fungsi keanggotaan dari semua label Error, . Error, dan . Tegangan. Form data digunakan untuk menampilkan data angka dari proses kendali logika fuzzy. Pada modull berisi prosedur prosedur yang berhubungan dengan design fungsi fuzzy. Pada modul2 berisi prosedur dan fungsi yang berhubungan dengan program utama yaitu proses perhitungan kendali logika fuzzy.

Algoritma perangkat lunak yang dipakai pada kendali logika fuzzy untuk mengendalikan kecepatan motor DC ini, yaitu:

a. Menginisialisasi PPI, menginisialisasi kondisi awal dan memberikan nilai waktu cuplik.

b. Mengambil batasan-batasan fungsi keanggotaan.

c. Memasukkan nilai referensi RPM.

d. Membaca Port B / Output Plant (NILPB).

e. Mengkonversi output plant menjadi kecepatan RPM.

f. Kecepatan RPM $=$ NILPB $* 60000 /$ Waktu cuplik / 32

g. Menghitung nilai error dan $\Delta$ error.

h. Error $(\mathrm{t})=$ Referensi - Kecepatan

i. $\quad \Delta \operatorname{Error}(\mathrm{t})=\operatorname{Error}(\mathrm{t})-\operatorname{Error}(\mathrm{t}-1)$

j. Proses fuzzifikasi, yaitu menghitung derajat keangggotaan semua label error dan $\Delta$ error.

k. Penggunaan operator AND dan melakukan proses implikasi yaitu menghitung derajat keanggotaan semua label $\Delta$ tegangan.

1. Proses komposisi yaitu mencari nilai maksimal derajat keanggotaan semua label $\Delta$ tegangan.

m. Mencari nilai $\Delta$ tegangan dari proses defuzzifikasi COA, bisektor, MOM, LOM, atau SOM.

n. Menghitung tegangan yang diberikan ke motor.

o. Tegangan $(\mathrm{t})=$ tegangan $(\mathrm{t}-1)+\Delta$ tegangan

p. Mengkonversi tegangan yang akan dikirimkan ke DAC melalui port A.

q. Port $\mathrm{A}=$ Tegangan $* 255 /$ tegangan maximal

r. Mengirim nilai PortA ke Port A PPI.

s. Tampilkan kecepatan RPM respon sistem terhadap waktu dalam bentuk grafik.

t. Simpan data Referensi, Error, $\Delta$ Error, $\Delta$ tegangan, tegangan, dan kecepatan RPM. 
u. Ulangi langkah 4 - 15 sampai tombol 'Stop' ditekan.

Sistem logika fuzzy yang di rancang mempunyai 2 input yaitu error dan $\Delta$ error serta 1 output yaitu $\Delta$ tegangan. Error dan $\Delta$ error di definisikan dengan rumus:

Error $(\mathrm{t})=$ Referensi - Kecepatan aktual

$\Delta$ error $(\mathrm{t})=\operatorname{Error}(\mathrm{t})-\operatorname{Error}(\mathrm{t}-1)$

Output yang diberikan plant di gunakan rumus:

Tegangan $(\mathrm{t})=$ tegangan $(\mathrm{t}-1)+\Delta$ tegangan

Dalam sistem ini di rancang fungsi keanggotaan error, $\Delta$ error dan $\Delta$ tegangan dengan jumlah label 7 label yaitu NB (Negatif Big), N (Negatif), NS (Negatif Small), Z (Zero), PS (Positif Small), P (Positif), dan PB (Positif Big). Fungsi keanggotaan input mempunyai bentuk trapesium dan segitiga serta output mempunyai bentuk singleton. Tabel 1, Tabel 2 dan Tabel 3 menunjukkan batasan-batasan fungsi keanggotaan error, $\Delta$ error dan $\Delta$ tegangan.

Tabel 1 Batasan-batasan fungsi keanggotaan error.

\begin{tabular}{|c|c|c|c|c|}
\hline $\begin{array}{c}\text { Label Fungsi } \\
\text { Keanggotaan } \\
\text { Error }\end{array}$ & $\begin{array}{c}\text { A } \\
\text { (RPM) }\end{array}$ & $\begin{array}{c}\text { B } \\
\text { (RPM) }\end{array}$ & $\begin{array}{c}\text { C } \\
\text { (RPM) }\end{array}$ & $\begin{array}{c}\text { D } \\
\text { (RPM) }\end{array}$ \\
\hline NB & -1600 & -1600 & -900 & -480 \\
\hline N & -900 & -480 & -480 & -60 \\
\hline NS & -120 & -60 & -60 & 0 \\
\hline Z & -20 & 0 & 0 & 20 \\
\hline PS & 0 & 60 & 60 & 120 \\
\hline P & 60 & 480 & 480 & 900 \\
\hline PB & 480 & 900 & 1600 & 1600 \\
\hline
\end{tabular}

Tabel 2 Batasan-batasan fungsi keanggotaan $\Delta$ error.

\begin{tabular}{|c|c|c|c|c|}
\hline $\begin{array}{c}\text { Label Fungsi } \\
\text { Keanggotaan } \\
\Delta \text { Error }\end{array}$ & $\begin{array}{c}\text { A } \\
\text { (RPM) }\end{array}$ & $\begin{array}{c}\text { B } \\
\text { (RPM) }\end{array}$ & $\begin{array}{c}\text { C } \\
\text { (RPM) }\end{array}$ & $\begin{array}{c}\text { D } \\
\text { (RPM) }\end{array}$ \\
\hline NB & -1600 & -1600 & -900 & -485 \\
\hline N & -900 & -485 & -485 & -70 \\
\hline NS & -140 & -70 & -70 & 0 \\
\hline Z & -20 & 0 & 0 & 20 \\
\hline PS & 0 & 70 & 70 & 140 \\
\hline P & 70 & 480 & 480 & 900 \\
\hline PB & 485 & 900 & 1600 & 1600 \\
\hline
\end{tabular}

Tabel 3 Batasan-batasan fungsi keanggotaan . tegangan.

\begin{tabular}{|c|c|}
\hline $\begin{array}{c}\text { Label Fungsi Keanggotaan } \\
\Delta \text { Tegangan }\end{array}$ & A (Volt) \\
\hline NB & $-5,4$ \\
\hline N & $-0,6$ \\
\hline NS & $-0,05$ \\
\hline Z & 0 \\
\hline PS & 0,05 \\
\hline P & 0,6 \\
\hline PB & 5,4 \\
\hline
\end{tabular}

Jumlah rule fuzzy yang digunakan pada sistem ini terdiri dari 49 rule, yaitu seperti pada Tabel 4.

Tabel 4 Basis aturan fuzzy.

\begin{tabular}{|c|c|c|c|c|c|c|c|}
\hline \multirow{2}{*}{\multicolumn{2}{|c|}{ Output }} & \multicolumn{7}{|c|}{ Error } \\
\cline { 2 - 8 } & NB & N & NS & Z & PS & P & PB \\
\hline NB & NB & N & NS & NB & PS & P & PB \\
\hline N & NB & N & NS & N & PS & P & PB \\
\hline NS & NB & N & NS & NS & PS & P & PB \\
\hline Z & NB & N & NS & Z & PS & P & PB \\
\hline PS & NB & N & NS & PS & PS & P & PB \\
\hline P & NB & N & NS & P & PS & P & PB \\
\hline PB & NB & N & NS & PB & PS & P & PB \\
\hline
\end{tabular}

\subsection{Pengujian dan Analisis}

Pada pengujian ini dilakukan pengujian dengan jumlah label yang sama pada semua fungsi keanggotaan yaitu 7 label dan beberapa variasi referensi yaitu pada kecepatan 700 RPM, 800 RPM, 900 RPM, 1000 RPM, dan 1100 RPM. Pada semua referensi diujikan batasanbatasan fungsi keanggotaan yang sama dan diujikan 5 sistem logika fuzzy dengan metode defuzzifikasi yang berbeda, yaitu COA, bisektor, MOM, LOM, dan SOM. Pengujian dilakukan tiga kali setiap pemberian referensi pada masingmasing metode defuzzifikasi dan diambil rataratanya.

Hasil dari pengujian ini adalah berupa respon sistem berbentuk grafis dan data yang diambil secara online. Grafik dan data tersebut dapat disimpan dalam bentuk file yang nantinya dapat digunakan untuk keperluan analisis diantaranya untuk mencari td, tr, dan ts dari respon sistem. 


\section{a. Referensi 700 RPM}

Pada pengujian pertama dengan memberian referensi 700 RPM dan menggunakan metode defuzzifikasi COA, bisektor, MOM, LOM, dan SOM didapatkan respon sistem seperti pada Gambar 9.

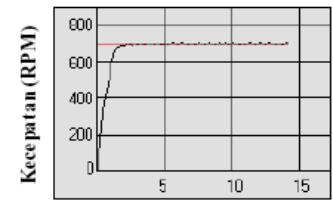

Waktu (detik)

(a) Defuzzifikasi COA

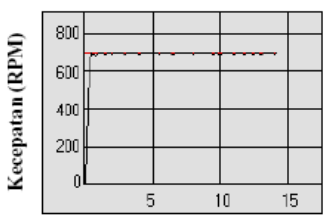

Waktu (detik)

(c) Defuzzifikasi MOM

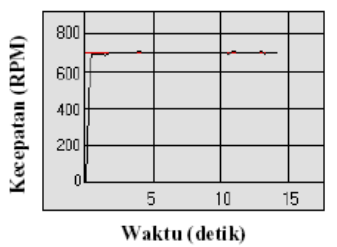

(e) Defuzzifikasi SOM

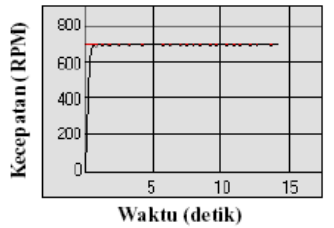

(b) Defuzzifikasi Bisektor

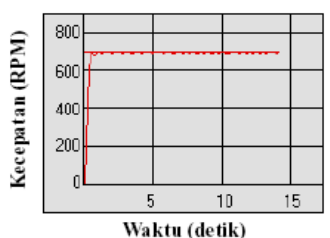

(d) Defuzzifikasi LOM
Gambar 9 Grafik respon sistem untuk referensi 700.

Dari tiga kali pengujian dengan memberikan referensi 700 RPM didapatkan rata-rata $t d$, tr, dan ts pada masing-masing defuzzifikasi seperti pada Tabel 5.

Tabel 5 Nilai rata-rata $\mathrm{Td}$, $\mathrm{Tr}$, dan Ts untuk referensi 700 RPM.

\begin{tabular}{|c|c|c|c|}
\hline Defuzzifikasi & $\begin{array}{c}\text { Td rata- } \\
\text { Rata (detik) }\end{array}$ & $\begin{array}{c}\text { Tr rata- } \\
\text { Rata (detik) }\end{array}$ & $\begin{array}{c}\text { Ts rata- } \\
\text { Rata (detik) }\end{array}$ \\
\hline COA & 0,4398 & 1,0793 & 1,3333 \\
\hline Bisektor & 0,1417 & 0,2642 & 0,4136 \\
\hline MOM & 0,1417 & 0,2627 & 0,4085 \\
\hline LOM & 0,1423 & 0,2734 & 0,4229 \\
\hline SOM & 0,1715 & 0,4489 & 0,5945 \\
\hline
\end{tabular}

Dari Tabel 5 terlihat bahwa $\mathrm{Td}$ terkecil diperoleh dengan menggunakan metode defuzzifikasi bisektor dan MOM yaitu sebesar
0,1417 detik, $\operatorname{Tr}$ terkecil diperoleh dengan menggunakan metode defuzzifikasi MOM yaitu sebesar 0,2627 detik, dan Ts terkecil diperoleh dengan menggunakan metode defuzzifikasi MOM yaitu sebesar 0,4085 detik .

\section{b. Referensi 800 RPM}

Pada pengujian pertama dengan memberian referensi 800 RPM dan menggunakan metode defuzzifikasi COA, bisektor, MOM, LOM, dan SOM didapatkan respon sistem seperti pada Gambar 10.
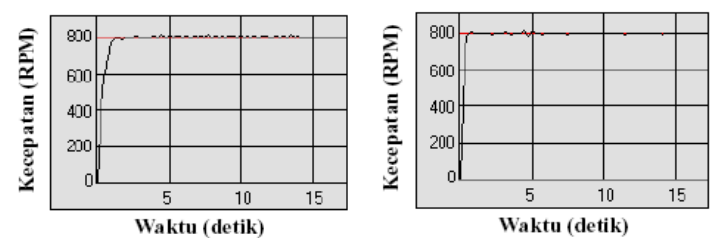

(a) Defuzzifikasi COA

(b) Defuzzifikasi Bisektor
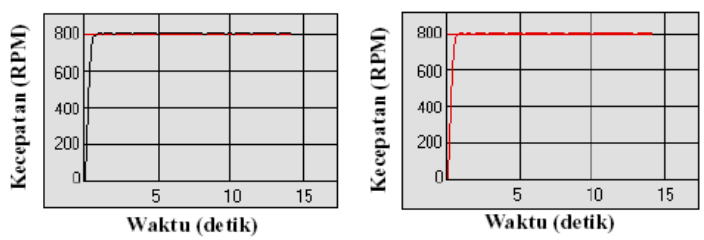

(c) Defuzzifikasi MOM

(d) Defuzzifikasi LOM

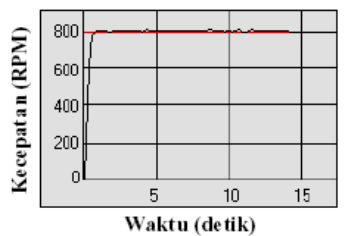

Gambar 10 Grafik respon sistem untuk referensi 800.

Dari tiga kali pengujian dengan memberikan referensi 800 RPM didapatkan rata-rata $t d$, tr, dan ts pada masing-masing defuzzifikasi seperti pada Tabel 6. 
Tabel 6 Nilai rata-rata Td, Tr, dan Ts untuk referensi 800 RPM.

\begin{tabular}{|c|c|c|c|}
\hline Defuzzifikasi & $\begin{array}{c}\text { Td rata- } \\
\text { Rata (detik) }\end{array}$ & $\begin{array}{c}\text { Tr rata- } \\
\text { Rata (detik) }\end{array}$ & $\begin{array}{c}\text { Ts rata- } \\
\text { Rata (detik) }\end{array}$ \\
\hline COA & 0,2299 & 0,8114 & 0,9718 \\
\hline Bisektor & 0,1619 & 0,3753 & 0,4692 \\
\hline MOM & 0,1626 & 0,3766 & 0,4697 \\
\hline LOM & 0,1626 & 0,3766 & 0,4697 \\
\hline SOM & 0,1626 & 0,3766 & 0,4697 \\
\hline
\end{tabular}

Dari Tabel 6 terlihat bahwa pada pemberian referensi 800 RPM Td terkecil diperoleh dengan menggunakan metode defuzzifikasi bisektor yaitu sebesar 0,1619 detik, Tr terkecil diperoleh dengan menggunakan metode defuzzifikasi bisektor yaitu sebesar 0,3753 detik, dan Ts terkecil diperoleh dengan menggunakan metode bisektor yaitu sebesar 0,4692 detik.

\section{c. Referensi 900 RPM}

Pada pengujian pertama dengan memberian referensi 900 RPM dan menggunakan metode defuzzifikasi COA, bisektor, MOM, LOM, dan SOM didapatkan respon sistem seperti pada Gambar 11.

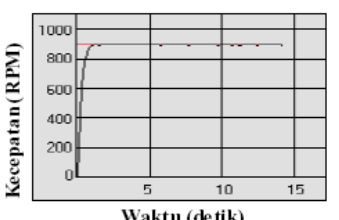

(a) Defuzzifikasi COA

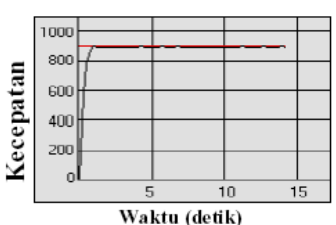

(c) Defuzzifikasi MOM

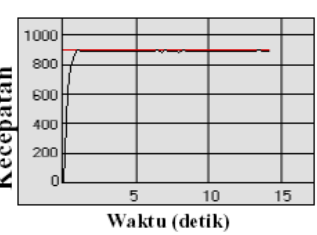

(e) Defuzzifikasi SOM

Gambar 11 Grafik respon sistem untuk referensi 900.

\begin{abstract}
(b) Defuzzifikasi Bisektor
\end{abstract}

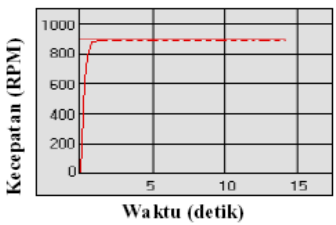

(d) Defuzzifikasi LOM
Dari tiga kali pengujian dengan memberikan referensi 900 RPM didapatkan rata-rata $t d$, tr, dan ts pada masing-masing defuzzifikasi seperti pada Tabel 7.

Tabel 7 Nilai rata-rata $\mathrm{Td}$, $\mathrm{Tr}$, dan Ts untuk referensi 900 RPM.

\begin{tabular}{|c|c|c|c|}
\hline Defuzzifikasi & $\begin{array}{c}\text { Td rata- } \\
\text { Rata (detik) }\end{array}$ & $\begin{array}{c}\text { Tr rata- } \\
\text { Rata (detik) }\end{array}$ & $\begin{array}{c}\text { Ts rata- } \\
\text { Rata (detik) }\end{array}$ \\
\hline COA & 0,1837 & 0,5443 & 0,6937 \\
\hline Bisektor & 0,1829 & 0,5426 & 0,6891 \\
\hline MOM & 0,1870 & 0,5358 & 0,6832 \\
\hline LOM & 0,1822 & 0,5320 & 0,6816 \\
\hline SOM & 0,1814 & 0,5370 & 0,6832 \\
\hline
\end{tabular}

Dari Tabel 7 terlihat bahwa Td terkecil diperoleh dengan menggunakan metode defuzzifikasi SOM yaitu sebesar 0,1814 detik, $\operatorname{Tr}$ terkecil diperoleh dengan menggunakan metode defuzzifikasi LOM yaitu sebesar 0,5320 detik, dan Ts terkecil diperoleh dengan menggunakan metode defuzzifikasi LOM yaitu sebesar 0,6816 detik.

\section{d. Referensi 1000 RPM}

Pada pengujian pertama dengan memberian referensi 1000 RPM dan menggunakan metode defuzzifikasi COA, bisektor, MOM, LOM, dan SOM didapatkan respon sistem seperti pada Gambar 12. 


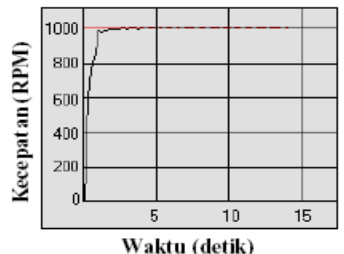

(a) Defuzzifikasi COA

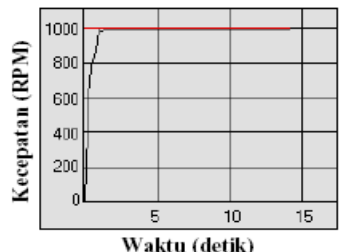

(c) Defuzzifikasi MOM

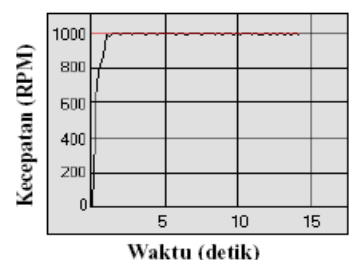

(e) Defuzzifikasi SOM

Gambar 12 Grafik respon sistem untuk referensi 1000 RPM.

Dari tiga kali pengujian dengan memberikan referensi 1000 RPM didapatkan rata-rata td, tr, dan ts pada masing-masing defuzzifikasi seperti pada Tabel 8 .

Tabel 8 Nilai rata-rata $\mathrm{Td}, \mathrm{Tr}$, dan Ts untuk referensi 1000 RPM.

\begin{tabular}{|c|c|c|c|}
\hline Defuzzifikasi & $\begin{array}{c}\text { Td rata- } \\
\text { Rata (detik) }\end{array}$ & $\begin{array}{c}\text { Tr rata- } \\
\text { Rata (detik) }\end{array}$ & $\begin{array}{c}\text { Ts rata- } \\
\text { Rata (detik) }\end{array}$ \\
\hline COA & 0,2075 & 0,7678 & 0,9288 \\
\hline Bisektor & 0,2041 & 0,7714 & 0,9268 \\
\hline MOM & 0,2050 & 0,7614 & 0,9188 \\
\hline LOM & 0,2033 & 0,7528 & 0,9187 \\
\hline SOM & 0,2041 & 0,7615 & 0,9188 \\
\hline
\end{tabular}

Dari Tabel 8 terlihat bahwa Td terkecil diperoleh dengan menggunakan metode defuzzifikasi LOM yaitu sebesar 0,2033 detik, $\mathrm{Tr}$ terkecil diperoleh dengan menggunakan metode defuzzifikasi LOM yaitu sebesar 0,7528 detik, dan Ts terkecil diperoleh dengan menggunakan metode defuzzifikasi LOM yaitu sebesar 0,9187 detik.

\section{e. Referensi 1100 RPM}

Pada pengujian pertama dengan memberian referensi 1100 RPM dan menggunakan metode defuzzifikasi COA, bisektor, MOM, LOM, dan SOM didapatkan respon sistem seperti pada Gambar 13

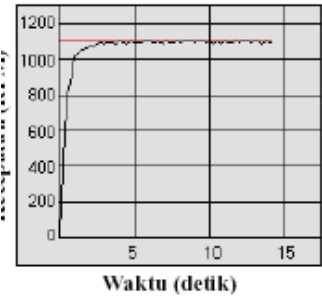

(a) Defuzzifikasi COA

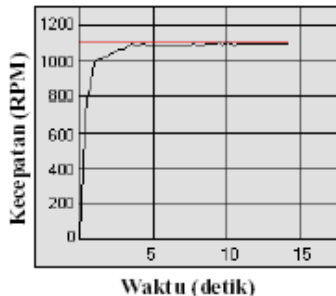

(c) Defuzzifikasi MOM

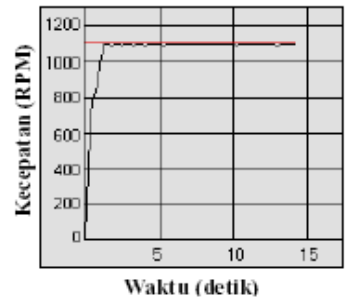

(b) Defuzzifikasi Bisektor

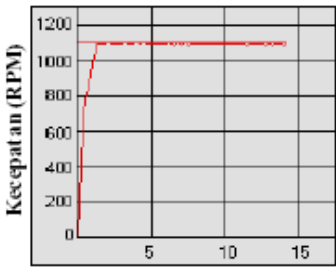

Waktu (detik)

(d) Defuzzifikasi LOM

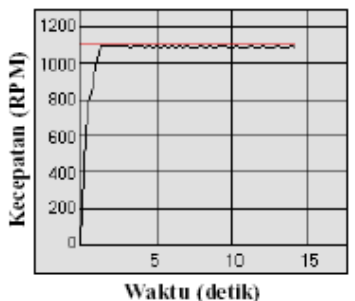

(e) Defuzzifikasi SOM

Gambar 13 Grafik respon sistem untuk referensi 1100 RPM.

Dari tiga kali pengujian dengan memberikan referensi 1100 RPM didapatkan rata-rata $\mathrm{Td}, \mathrm{Tr}$, dan Ts pada masing-masing defuzzifikasi seperti pada Tabel 9.

Tabel 9 Nilai rata-rata $\mathrm{Td}$, $\mathrm{Tr}$, dan $\mathrm{Ts}$ untuk referensi 1100 RPM.

\begin{tabular}{|c|c|c|c|}
\hline Defuzzifikasi & $\begin{array}{c}\text { Td rata- } \\
\text { Rata (detik) }\end{array}$ & $\begin{array}{c}\text { Tr rata- } \\
\text { Rata (detik) }\end{array}$ & $\begin{array}{c}\text { Ts rata- } \\
\text { Rata (detik) }\end{array}$ \\
\hline COA & 0,2227 & 0,9328 & 1,3687 \\
\hline Bisektor & 0,2245 & 0,9607 & 2,0028 \\
\hline MOM & 0,2218 & 0,9556 & 2,2639 \\
\hline LOM & 0,2284 & 0,9718 & 1,4016 \\
\hline SOM & 0,2218 & 0,9723 & 1,3833 \\
\hline
\end{tabular}


Dari Tabel 9 terlihat bahwa $\mathrm{Td}$ terkecil diperoleh dengan menggunakan metode defuzzifikasi MOM dan SOM yaitu sebesar 0,2218 detik, $\operatorname{Tr}$ terkecil diperoleh dengan menggunakan metode defuzzifikasi COA yaitu sebesar 0,9328 detik, dan Ts terkecil diperoleh dengan menggunakan metode defuzzifikasi COA yaitu sebesar 1,3687 detik.

Dari semua pengujian pemberian referensi dan penggunaan semua metode defuzzifikasi maka dapat dihitung nilai rata-rata $\mathrm{Td}, \mathrm{Tr}$, dan Ts seperti pada Tabel 10 .

Tabel 10 Nilai Td, Tr, dan Ts untuk referensi 700 RPM sampai 1100 RPM.

\begin{tabular}{|c|c|c|c|c|c|c|c|}
\hline \multirow{2}{*}{$\begin{array}{c}\text { Defuzzi } \\
\text { fikasi }\end{array}$} & \multirow{2}{*}{$\begin{array}{c}\text { Parameter } \\
\text { (detik) }\end{array}$} & \multicolumn{5}{|c|}{ Referensi (RPM) } & \multirow{2}{*}{$\begin{array}{l}\text { Rata- } \\
\text { rata }\end{array}$} \\
\hline & & 700 & 800 & 900 & 1000 & 1100 & \\
\hline \multirow{3}{*}{$\mathrm{COA}$} & td & 0,4398 & 0,2299 & 0,1837 & 0,2075 & 0,2227 & 0,2567 \\
\hline & to & 0793 & 0,8114 & 0,5443 & 0,7678 & 0,9328 & 0,8271 \\
\hline & ts & 3333 & 0,9718 & 0,6937 & 0,9288 & 1,3687 & 1,0592 \\
\hline \multirow{3}{*}{ Bisektor } & td & 0,1417 & 0,1619 & 0,1829 & 0,2041 & 0,2245 & 0,1830 \\
\hline & tr & 42 & 53 & 26 & 14 & 0,9607 & 0,5828 \\
\hline & ts & 36 & 92 & 0,6891 & 0,9268 & & 0,8000 \\
\hline \multirow{3}{*}{ MOM } & $\mathrm{td}$ & 17 & 0 , & 0,1870 & 0,2050 & 0,2218 & 0,1836 \\
\hline & tr & 0,2627 & 0,3766 & 0,5358 & 0,7614 & 0,9556 & 0,5784 \\
\hline & ts & 0,4085 & 0,4697 & 0,6832 & 0,9188 & 2,2639 & 0,9488 \\
\hline \multirow{3}{*}{ LOM } & $\mathrm{td}$ & 0,1423 & 0,1626 & 0,1822 & 0,2033 & 0,2284 & 0,1838 \\
\hline & tr & 0,2734 & 0,3766 & 0,5320 & 0,7528 & 0,9718 & 0,5813 \\
\hline & Is & 0,4229 & 0,4697 & 0,6816 & 0,9187 & 1,4016 & 0,7789 \\
\hline \multirow{3}{*}{ SOM } & td & 0,1715 & 0,1626 & 0,1814 & 0,2041 & 0,2218 & 0,1883 \\
\hline & tr & 0,4489 & 0,3766 & 0,5370 & 0,7615 & 0,9723 & 0,6193 \\
\hline & ts & 0,5945 & 0,4697 & 0,6832 & 0,9188 & 1,3833 & 0,8099 \\
\hline
\end{tabular}

Dari Tabel 10 terlihat bahwa nilai rata-rata $\mathrm{Td}$ terkecil dari lima kali variasi pemberian referensi adalah dengan menggunakan metode defuzzifikasi bisektor yaitu sebesar 0,1830 detik. Nilai rata-rata $\operatorname{Tr}$ terkecil dengan menggunakan metode defuzzifikasi MOM yaitu sebesar 0,5784 detik dan nilai rata-rata Ts terkecil dengan menggunakan metode defuzzifikasi LOM yaitu sebesar 0,7789 detik.

Dari grafik dan data hasil pengujian terlihat bahwa sistem tidak mengalami lonjakan. Hal ini disebabkan karena pada saat kecepatan motor DC semakin mendekati dari referensi yang diberikan, sistem logika fuzzy dapat mengambil keputusan memberikan tegangan yang semakin kecil juga.
Dari grafik dan data yang didapat juga dapat diambil kesimpulan bahwa metode defuzzifikasi yang terbaik mengikuti referensi adalah metode COA. Hal ini disebabkan karena hasil nilai dari penggunaan metode defuzzifikasi diambil dari titik pusat pada daerah fuzzy.

\section{Penutup}

\subsection{Kesimpulan}

Berdasarkan hasil pengujian yang dilakukan didapatkan hal-hal penting sebagai berikut :

a. Nilai rata-rata td terkecil dari lima defuzzifikasi adalah dengan menggunakan metode defuzzifikasi bisektor yaitu sebesar 0,1830 detik.

b. Nilai rata-rata tr terkecil dari lima defuzzifikasi adalah dengan menggunakan metode defuzzifikasi MOM yaitu sebesar 0,5784 detik.

c. Nilai rata-rata ts terkecil dari lima defuzzifikasi adalah dengan menggunakan metode defuzzifikasi LOM yaitu sebesar 0,7789 detik.

d. Pengendalian motor DC dengan sistem logika fuzzy tidak terdapat lonjakan.

e. Diantara kelima metode defuzzifikasi, metode defuzzifikasi yang terbaik selalu mengikuti referensi adalah metode COA.

f. Baik dan tidaknya penggunaan metode defuzzifikasi model Mamdani pada sistem kendali logika fuzzy sangat tergantung dari perancangan fungsi keanggotaan dan basis aturan fuzzy yang digunakan.

\subsection{Saran}

a. Untuk mendapatkan hasil pengaturan yang lebih presisi bisa digunakan DAC dan pencacah yang mempunyai resolusi lebih tinggi, misalkan dengan DAC/pencacah 12 bit.

b. Plant motor DC ini masih bisa dikembangkan lagi dengan mengubah controller yang digunakan, misalkan dengan Algoritma Genetik dan Jaringan Syaraf.

\section{Daftar Pustaka}

[1] Budiharto, Widodo, Interfacing Komputer dan Mikrokontroler, Jakarta: Elexmedia komputindo, 2004. 
[2] Jun Y., Michail R., James P., Using Fuzzy Logic, 1993.

[3] Kusumadewi, Sri, Analisis dan Desain Sistem Fuzzy menggunakan Toolbox Matlab, Yogyakarta: Geaha Ilmu, 2002.

[4] Link, Wolfgang., Pengukuran, Pengendalian dan Pengaturan dengan PC. PT Elex Media Komputindo. Jakarta.
[5] M. Passino, Kevin, Yurkovich, Stephen, Fuzzy Control, Addison-Wesley Longman Inc., California, 1998.

[6] Ogata, Katsuhiko. Alih bahasa Edi Leksono, Teknik Kontrol Automatik (Sistem Pengaturan). Jilid 1. Jakarta : Erlangga. 1994.

[7] Tjokronegoro, Hariyono A., Identifikasi Parameter Sistem, Jurusan Teknik Fisika, Institut Teknologi Bandung, 1996. 
Perbandingan Metode Defuzzifikasi Sistem Kendali Logika Fuzzy Model Mamdani pada Motor Dc 